\title{
MODEL COMPLEMENT AND FOCUS DALAM PENANGANAN PASCA BENCANATAHAP REHABILITASI (Studi Kasus pada Peristiwa Gempa Bumi di Klaten, 27 Mei 2006)
}

\author{
Qomarun \\ Fakultas Teknik \\ Universitas Muhammadiyah Surakarta
}

\section{ABSTRACT}

The objective of this model is to cover the interest of both donor and acceptor of aid in the event of post disaster. The complement and focus model is being developed in the fact of their condition which is almost the same. Complement model is conducted by sharing power, while focus model is conducted by centralization of scope. To approach the objective, the activities are conducted by design and build pattern. Afterwards, the try and error model should be developed to cover both the lack of literature and the speed of changing. In this case study, we found the new activity which was called demolition program in handling post earthquake disaster. The main activity of that program is destroying and cleaning the built environment which is almost collapse. Actually, this activity is really helpful for some people in the field, although we have yet to design.

Keywords: complement, focus, domisili.

\section{PENDAHULUAN}

\section{Analisis Situasi}

Pada hari Sabtu, 27 Mei 2006, sekitar jam 06.00 pagi, di Klaten dan Yogyakarta terjadi gempa bumi tektonik yang mempunyai kekuatan gempa mencapai 5,9 SR, (BMG Pusat mencatat 6,2 SR). Bencana alam ini telah menelan korban di atas lima ribu orang meninggal, puluhan ribu luka dan lebih dari lima puluh ribu bangunan roboh.

Dalam rangka ikut mewujudkan Tri Darma Perguruan Tinggi UMS, dalam hal ini pada bidang Pengabdian Masyarakat, maka disusun kegiatan untuk membantu masyarakat korban bencana di Klaten sehingga mereka segera pulih dari keterpurukan kondisi fisik dan sekaligus segera dapat menjalankan segala aktivitasnya sehari-hari. Warga masyarakat di Kabupaten Klaten setelah gempa 
tersebut pada umumnya telah mengalami banyak kehilangan harta benda, kehilangan anggota keluarga dan bahkan kehilangan semangat hidupnya. Pihakpihak pemberi bantuan baik berupa harta, tenaga atau pikiran dari pihak individu, kelompok atau bahkan negara asing tentu sangat membantu masyarakat korban bencana.

\section{Perumusan Masalah}

Penanganan korban pasca bencana adalah kegiatan yang merupakan gabungan antara ilmu dan amal. Paradigma pengabdian yang telah berkembang ke arah profit-oriented thinking tentu untuk kasus penanganan bencana harus digabungkan dengan paradigma cost-oriented thinking yang telah lama ditinggalkan. Dalam rangka ikut memberi bantuan kepada para korban bencana di Klaten (pemenuhan pola ilmiah pokok UMS yang profetik-istislah), tentu dibutuhkan dana, tenaga dan pikiran yang besar. Pada sisi yang lain, kondisi internal para pengabdi yang juga terbatas haruslah dipertimbangkan juga. Sehingga dari kesenjangan ini dibutuhkan solusi atas:

1) Bagaimana konsep kegiatan pengabdian yang ideal?

2) Bagaimana langkah-langkah pelaksanaannya?

\section{Tinjauan Pustaka}

\section{a. Bencana Gempa Bumi}

Bencana gempa bumi merupakan kejadian alam yang tidak dapat diduga secara akurat, bahkan oleh seorang ahli yang berkompeten pada bidangnya sekalipun. Wilayah Indonesia secara geografis dilintasi oleh garis gempa global, yang dalam dunia geologi disebut sebagai kawasan Ring of Fire. Berdasarkan data Katalog Gempa (1629-2005), Indonesia telah mengalami gempa bumi tektonik yang diikuti dengan bencana tsunami sampai 99 kali. Peristiwa tsunami di Indonesia tercatat 109 kali, dimana 99 kali karena gempa, 9 kali karena gunung berapi yang meletus dan 1 kali karena landslide (tanah longsor). Gempa bumi yang diikuti dengan gelombang tsunami di Pangandaran pada pertengahan tahun 2006 telah melengkapi data statistik tersebut menjadi 100 kali bencana dalam 400 tahun terakhir. Jadi dari data ini dapat diambil rata-rata, bahwa setiap empat tahun sekali di Indonesia akan terjadi gempa yang diikuti tsunami. Gempa bumi di Aceh pada akhir tahun 2004 yang diikuti dengan gelombang tsunami, tercatat sebagai gempa terparah sepanjang sejarah.

44 WARTA, Vol .10, No. 1, Maret 2007: 43 - 52 
Gempa bumi hingga sekarang ini lazim diukur dengan dua skala pengukuran, yaitu Skala Richter(SR) dan Skala Mercalli(SM). SR diciptakan oleh Charles F. Richter pada tahun 1935 dan SM diciptakan oleh Giuseppe Mercalli pada tahun 1902(Solo Pos, 2005). SR menekankan pada pengukuran tingkat kekuatan gempa berdasarkan data getaran atau goncangan yang terekam pada alat pengukur gempa atau seismograf. Sementara SM dihitung berdasarkan pada tingkat kerusakan yang terjadi pada sebuah wilayah gempa. Sebagai gambaran, maka berikut ini disajikan tabel spesifikasi dua skala tersebut dan dampaknya.

\section{b. Fase-fase Penanganan Pasca Bencana}

Berdasarkan standar penanganan pasca bencana, maka di lokasi bencana umumnya berturut-turut dilakukan tindakan evakuasi, rehabilitasi dan rekonstruksi (Darmanto, 2006). Tahap evakuasi adalah serangkaian kegiatan untuk mengeluarkan korban dari lokasi bencana ke lokasi baru yang lebih aman. Tahap ini selain untuk memindahkan korban yang masih hidup ke tempat yang lebih aman, juga untuk mengambil korban yang sudah meninggal ke tempat yang lebih mudah dijangkau. Tahap evakuasi umumnya dilakukan oleh pihak-pihak yang sudah berpengalaman dalam hal ini, seperti Tim SAR, PMI, IRC, TNI/Polri, Depsos, LSM dan para relawan. Pada proses evakuasi, biasanya yang sangat dibutuhkan adalah sarana-prasarana kesehatan, transportasi, komunikasi dan posko (temporary shelter).

Sementara tahap rehabilitasi, yang umumnya dilakukan pada satu minggu setelah bencana, adalah serangkaian tindakan yang ke arah perbaikan fisik pada lokasi bencana, seperti pembenahan jalur-jalur jalan yang vital, pengadaan alat-alat transportasi dan komunikasi, serta penambahan saranaprasarana temporary shelter. Pada tahap ini selain berupa tindakan-tindakan ke arah perbaikan fisik atau bangunan, maka juga mulai ada tindakan-tindakan yang ke arah perbaikan mental atau psikis masyarakat korban bencana. Masyarakat yang terkena bencana umumnya masih shock dan labil dalam menghadapi kehidupan sehari-harinya. Pihak-pihak yang membantu tahap ini biasanya masih sama dengan tahap evakuasi namun ditambah dengan beberapa tokoh masyarakat, pemuka agama, pimpinan rakyat, pihak famili dan sebagainya, guna membangun semangat (perbaikan psikis).

Pada tahap berikutnya, maka disusul tahap rekonstruksi yang berupa pembangunan kembali bangunan-bangunan di lokasi bencana, baik 
bangunan milikumummaupun perorangan. Persoalan yang selalu muncul pada tahap ini adalah keterbatasan kemampuan, baik berupa ilmu, biaya dan tenaga. Selain masyarakat telah kehilangan banyak harta benda, kehilangan anggota keluarga dan kehilangan semangat hidupnya karena bencana, maka beban rekonstruksi fisik tentu semakin memberatkan mereka. Pihak-pihak pemberi bantuan baik berupa harta, tenaga atau pikiran dari pihak individu, kelompok atau bahkan negara tentu sangat membantu masyarakat korban bencana.

\section{METODE PENERAPAN IPTEKS \\ 1. Kerangka Pemecahan Masalah}

Persoalan yang selalu muncul pada penanganan pasca bencana adalah keterbatasan kemampuan, baik kemampuan biaya atau tenaga atau bahkan ilmu pengetahuan. Masyarakat korban bencana yang telah kehilangan banyak harta benda, kehilangan anggota keluarga dan bahkan kehilangan semangat hidupnya tentu tidak dapat berbuat banyak kecuali menunggu bantuan. Pihakpihak pemberi bantuan baik berupa harta, tenaga atau pikiran dari pihak individu, kelompok atau bahkan negara tentu sangat ditunggu-tungu oleh masyarakat korban bencana. Dalam rangka ikut memberi bantuan namun pada sisi yang lain pemberi bantuan juga terdapat banyak keterbatasan internal, maka disusun konsep complement and focus dalam kegiatan pengabdian masyarakat ini. Penanganan pasca bencana tahap rehabilitasi harus melihat dua aspek sekaligus, yaitu aspek keinginan dan kemampuan. Titik temu dari dua aspek tersebut dapat dilakukan dengan penggabungan model complement and focus, yaitu suatu model yang mempunyai pola bahwa kekuatan akan lebih berdaya-guna apabila terjadi penggabungan (complement) dari dua kekuatan atau lebih. Sedangkan model focus adalah suatu model yang mempunyai pola terpusat atau terkonsentrasi pada satu obyek tertentu dari berbagai obyek yang ada, atau dengan kata lain 'kecil tapi tuntas'. Perpaduan antara model complement dan focus yang kemudian disebut sebagai model complement and focus dipilih dalam pelaksanaan kegiatan pengabdian masyarakat di Klaten, khususnya pada kasus penanganan pasca bencana tahap rehabilitasi, karena memenuhi aspek keinginan dan kemampuan.

\section{Realisasi Pemecahan Masalah}

Wujud nyata dari konsep itu adalah dengan melakukan penggabungan kegiatan dosen dan mahasiswa. Dalam rangka ikut memberi bantuan kepada

46 WARTA, Vol .10, No. 1, Maret 2007: 43 - 52 
para korban bencana di Klaten, maka pihak dosen berkomplementer dengan mahasiswa Teknik Arsitektur FT-UMS yang telah membentuk tim yang bernama ‘Arsitektur Peduli Gempa Klaten’. Setelah melakukan penggabungan kekuatan dan spesifikasi kegiatan, maka obyek kegiatan harus memenuhi kaidah focus, yaitu 'kecil tapi tuntas'. Lokasi bantuan yang dipilih berdasarkan atas kategori tingkat keparahan, adanya akses yang mudah serta tingkat besaran kawasan administrasi pemerintahan terkecil. Berdasarkan kriteria tersebut, maka Desa Kadilanggon Kecamatan Wedi Kabupaten Klaten, terpilih sebagai lokasi bantuan.

\section{Khalayak Sasaran}

Masyarakat korban bencana di Desa Kadilanggon Kecamatan Wedi Kabupaten Klaten adalah khalayak sasaran kegiatan. Pihak-pihak yang terlibat (atau disebut sebagai khalayak sasaran antara) dalam kegiatan ini mempunyai motivasi utama untuk beramal atau bersedekah. Spirit ini selalu melekat pada kegiatan-kegiatan yang mengatasnamakan peduli bencana dimanapun berada. Selain itu, adanya pemberitaan dari beberapa media (cetak atau elektronik) mampu menjadikan kegiatan pengabdian ini lebih cepat dikenal di masyarakat lokal, regional, nasional atau bahkan intemasional, sehingga bantuan dari beberapa sumber juga lebih cepat berdatangan. Pihak-pihak yang strategis sebagai penguat dan pendukung dalam kegiatan ini adalah pihak LSM (PMI, IRC, IOM, dll), institusi (universitas, pemerintah, perusahaan, dll), kumpulan individu (donatur, klub, umat, group dll) atau individu (konglomerat, pengusaha, tokoh dll).

\section{Metode yang Digunakan}

Metode yang digunakan mirip dengan model design and build dalam dunia jasa konstruksi, yaitu sambil merancang sambil dikerjakan. Hal ini harus dilakukan karena kondisi di lapangan membutuhkan penanganan yang cepat dan efektif. Langkah-langkah utama dalam pengabdian masyarakat ini terbagi menjadi 3 macam, yaitu

(1) persiapan;

(2) pelaksanaan; dan

(3) penyempurnaan di lapangan.

Langkah pertama berupa serangkaian kegiatan koordinasi, kegiatan survey dan perijinan, serta pengadaan sarana dan prasarana (logistik awal). Tahap kedua berupa serangkaian kegiatan lapangan, yaitu pembuatan posko, 
pembenahan sarana-prasarana, penyebaran informasi, pengumpulan dan pembagian logistik/donatur, pembenahan lingkungan binaan (rehabilitasi). Langkah ketiga adalah langkah-langkah penyempurnaan ketika di lapangan, yaitu penerapan model try and error. Kegiatan pengabdian masyarakat yang berupa penanganan pasca bencana diharapkan terus berlanjut meskipun pihak pioneer telah selesai di lapangan. Kegiatan akan diteruskan oleh pihak pemerintah atau justru dari swadaya masyarakat sehingga kehidupan sosio-ekonomi dapat berangsur-angsur pulih kembali. Evaluasi akan dilakukan setiap minggu sekali selama tiga bulan untuk memantau kegiatan rehabilitasi di Desa Kadilanggon, Kecamatan Wedi Kabupaten Klaten. Evaluasi yang berupa kegiatan untuk mendapatkan efisiensi dan efektifitas kinerja, akan dilakukan oleh beberapa tim-tim kecil sesuai spesifikasi pekerjaannya.

\section{HASIL DAN PEMBAHASAN}

\section{Aktivitas Persiapan}

a) Koordinasi Tim

Seperti konsep di awal, pengabdian ini menggunakan format complement, yaitu melengkapi kekuatan yang ada di antara dosen dan mahasiswa. Mahasiswa yang mempunyai power besar, dalam artian jumlah, tenaga dan semangat berperan yang tinggi, akan dilengkapi dengan kendali pikir dan bantuan logistik dari dosen-dosen sehingga semakin berdayaguna. Koordinasi antara pihak dosen dan mahasiswa terjadi sambil berjalan, karena kondisi lapangan membutuhkan langkah-langkah yang sangat cepat. Bahkan koordinasi melalui komunikasi (hand-phone) harus dilakukan untuk mengejar tingkat kekritisan obyek pengabdian.

b) Survey

Setelah melakukan pelengkapan kekuatan (complement), maka konsep kegiatan harus memenuhi kaidah focus, yaitu 'kecil tapi tuntas'. Lokasi bantuan yang dipilih berdasarkan atas kategori tingkat keparahan, adanya akses yang mudah serta tingkat besaran kawasan administrasi pemerintahan terkecil adalah Desa Kadilanggon Kecamatan Wedi Kabupaten Klaten. Untuk memudahkan operasional, posko ditempatkan satu lokasi dengan rumah kepala desa setempat.

48 WARTA, Vol .10, No. 1, Maret 2007: 43 - 52 
c) Logistik Awal

Untuk kelancaran aktivitas di lapangan, maka melalui pihak dekanat (dalam hal ini PD III) tim pengabdi membantu menyiapkan logistik yang berupa transportasi (mobil pick-up), tenda-tenda besar, tikar dan peralatan listrik. Logistik awal ini menjadi modal utama di lapangan untuk 3 bulan ke depan.

d) Perijinan

Pada saat terjadi aktivitas awal tersebut, pihak Bapeda Klaten juga sedang meminta bantuan Fakultas TeknikUMS, sehingga proses perijinan dapat berjalan lancar. Seluruh kecamatan di Klaten (26 kecamatan) telah diberikan surat tembusan untuk membantu pihak universitas yang ikut terlibat dalam kegiatan penanganan pasca bencana.

\section{Aktivitas Pelaksanaan}

a) Pembuatan Posko dan Pembenahan Sekitarnya

Setelah proses persiapan selesai dilakukan, maka proses berikutnya adalah ke lapangan. Kegiatan awal adalah berupa pembenahan posko dan sarana-prasarananya. Sebagai suatu base-camp, maka posko harus mampu dijadikan pusat aktivitas di lapangan dengan minimum waktu untuk tiga bulan kedepan. Kebutuhan makan, minum, tidur, mandi dan ibadah dari tim harus mampu dipenuhi meskipun dengan standar temporary shelter. Untuk memenuhi kebutuhan tersebut, maka telah didapatkan logistik berupa tenda-tenda besar, tikar dan sleeping bag, serta peralatan mandi, untuk melengkapi posko yang berada di rumah kepala desa.

b) Pengumpulan dan Pembagian Bantuan

Setelah proses pembenahan posko selesai dilakukan, maka pada tahap berikutnya adalah pengumpulan bantuan dan penyebaran informasi melalui berbagai asosiasi dan institusi. Bantuan awal dari institusi UMS yang berupa dana dan logistik cukup sebagai modal awal di lapangan. Untuk tahap berikutnya maka dilakukan komunikasi dengan khalayak sasaran antara, yaitu pihak LSM (PMI, IRC, IOM, dll), institusi (universitas, pemerintah, perusahaan, dll), kumpulan individu (donatur, klub, umat, group dll) atau individu (konglomerat, pengusaha, tokoh dll). Masyarakat 
korban bencana umumnya sangat aktif mengunjungi posko untuk meminta bantuan sesuai kondisi wilayah masing-masing.

Selain itu, hasil kerja keras para tim mahasiswa di lapangan melalui komunikasi dan kerjasama antar institusi, LSM, pemerintah, individu, atau donator lain juga mulai mendapatkan hasil, sehingga bantuan mulai berdatangan untuk didistribusikan ke masyarakat korban bencana.

c) Pembenahan Lingkungan Binaan

Selain kegiatan pengumpulan dan pembagian bantuan tersebut, tim lapangan juga telah melakukan kegiatan pembenahan lingkungan binaan. Pembenahan ini lebih cepat dari skedul yang telah direncanakan. Kondisi lapangan lebih cepat berubah dan lebih kritis keadaannya dari dugaan semula. Rumah-rumah yang telah menjadi puing-puing bangunan sulit dijadikan tempat untuk aktivitas apapun. Untuk dijadikan bangunan kembali, masyarakat tidak ada dana dan tenaga, namun untuk dihuni kembali juga tidak memungkinkan karena telah roboh dan berserakan.

Dalam kondisi ini, akhirnya keluar solusi demolisi, yaitu penghancuran dan pembersihan lahan dari segala bangunan dan puingpuingnya sehingga areanya menjadi bersih dan dapat dijadikan tempat temporary shelter atau fungsi lainnya. Pembenahan lingkungan binaan yang berupa model demolisi sangat membantu warga setempat, sehingga setiap hari banyak warga masyarakat mendaftarkan diri kepada tim untuk menjadikan rumahnya sebagai obyek demolisi. Tim mahasiswa bersama-sama masyarakat dan TNI bergabung dan bergotong royong untuk melakukan proses demolisi dengan peralatan manual, seperti tali tambang, martil, pacul, sekop, linggis dan peralatan sederhana lainnya. Rata-rata setiap hari kegiatan ini mampu menyelesaiakan satu rumah, sehingga semakin hari semakin banyak rumah yang berstatus lahan kosong dan siap bangun. Proses demolisi adalah proses yang tidak direncanakan namun justru sangat dibutuhkan pada masyarakat korban bencana, khususnya penanganan pasca bencana tahap rehabilitasi.

\section{SIMPULAN DAN REKOMENDASI a. Simpulan}

Penanganan pasca bencana adalah kegiatan yang membutuhkan dana, tenaga, waktu dan pikiran yang sangat besar. Kegiatan lapangan yang mengarah kepada spirit amal dan penerapan ilmu harus dilakukan karena kondisi korban

50 WARTA, Vol .10, No. 1, Maret 2007: 43 - 52 
bencana secara fisik dan psikis umumnya juga membutuhkan keduanya. Metode pelaksanaan yang berpola design and build harus ditempuh karena hal ini mempercepat proses penanganan pasca bencana, khususnya pada tahap rehabilitasi. Metode pengabdian complement and focus berhasil lancar dilaksanakan di lapangan dan masing-masing pihak yang terkait mampu mendapatkan nilai tambah dari kegiatan yang dilakukan. Pada kegiatan pengabdian ini ditemukan tema baru dalam penanganan pasca bencana pada tahap rehabilitasi, yaitu kegiatan demolisi. Kegiatan yang berbentuk penghancuran dan pembersihan bangunan-bangunan korban bencana mempunyai kemanfaatan yang sangat tinggi bagi masyarakat.

Berdasarkan kondisi geografisnya, wilayah Indonesia terutama selatan Jawa berpotensi tinggi mendapatkan bencana gempa berkekuatan besar, yaitu diatas 6 SR. Bahkan dalam data katalog gempa, di Indonesia rata-rata akan terjadi gempa yang diikuti tsunami setiap empat tahun sekali. Oleh karena itu, dengan rendahnya dan lambannya pihak penyelenggara negara (atau yang berwenang) bareaksi terhadap hal ini, tentu dibutuhkan kekuatan-kekuatan lain yang mampu mengisi atau saling melengkapi penanganan masalah bencana. Model complement and focus dapat digunakan dalam penanganan pasca bencana, karena selain mampu memperbaiki keadaan korban bencana dengan cara berpatungan dari berbagai kekuatan maka produknya juga dapat jelas dan terarah.

\section{b. Rekomendasi}

Rekomendasi tindak lanjut yang dapat disampaikan dalam studi ini adalah dibutuhkan adanya teamwork antara pemerintah dan pihak jasa konstruksi (kontraktor) yang dapat siaga mendatangkan alat-alat beratnya untuk membantu tahap pembersihan jalur vital, karena terbukti kondisi pasca bencana selalu dibarengi dengan puing-puing yang sangat besar dan banyak. Setelah jalurjalur penting dapat diakses, maka penanganan fisik berupa demolisi dan rehabilitasi dapat dilakukan dengan kendali pemerintah yang dibantu militer, LSMdan institusi, sehingga masing-masing kekuatan mampu saling melengkapi.

\section{DAFTAR PUSTAKA}

Darmanto. 2006. "Pengalaman dari Penanganan Bencana Alam di Yogyakarta.”. Makalah RAPI V. Surakarta: Fakultas Teknik UMS. 
Longman. 2000. The Theory of Plate Tectonics. New York: CD-Toefl.

Porter, Michael E. 1990. Strategi Bersaing: Teknik Menganalisis Industri dan Pesaing(Terjemahan). Jakarta: Penerbit Erlangga.

Qomarun. 2000. Manajemen Proyek: Buku Pegangan Kuliah UMS. Surakarta: Jurusan Arsitektur FT-UMS.

Rahman, Arief. 2006. "Disaster Emergency Response Information System”. Makalah RAPI V. Surakarta: Fakultas Teknik UMS.

Wajdi, M.Farid. 2000. Pedoman Pelaksanaan Pengabdian pada Masyarakat. Surakarta: LPM-UMS.

Website.2006. Materi Gempa dan Penanganan Pasca Bencana: www.usgs.com, www.solopos.com, www.jawapos.com, www.metrotvnews.com, ww.detik.com, www.kompas.com.

52 WARTA, Vol .10, No. 1, Maret 2007: 43 - 52 
54 WARTA, Vol .10, No. 1, Maret 2007: 43 - 52 


$$
\text { Rt.03/ ras. }
$$

linta bantuan tenda franena. bany ak anaks fecid. tiokurya ciluwar tidat makal ating? s. betu me den sesu dakny a kami dari warg a mo ja rakan D dr. Bukurogo. mengucaptan terimakagib.

Gapat det.os. Bapat te woo. oty. Lanjai.
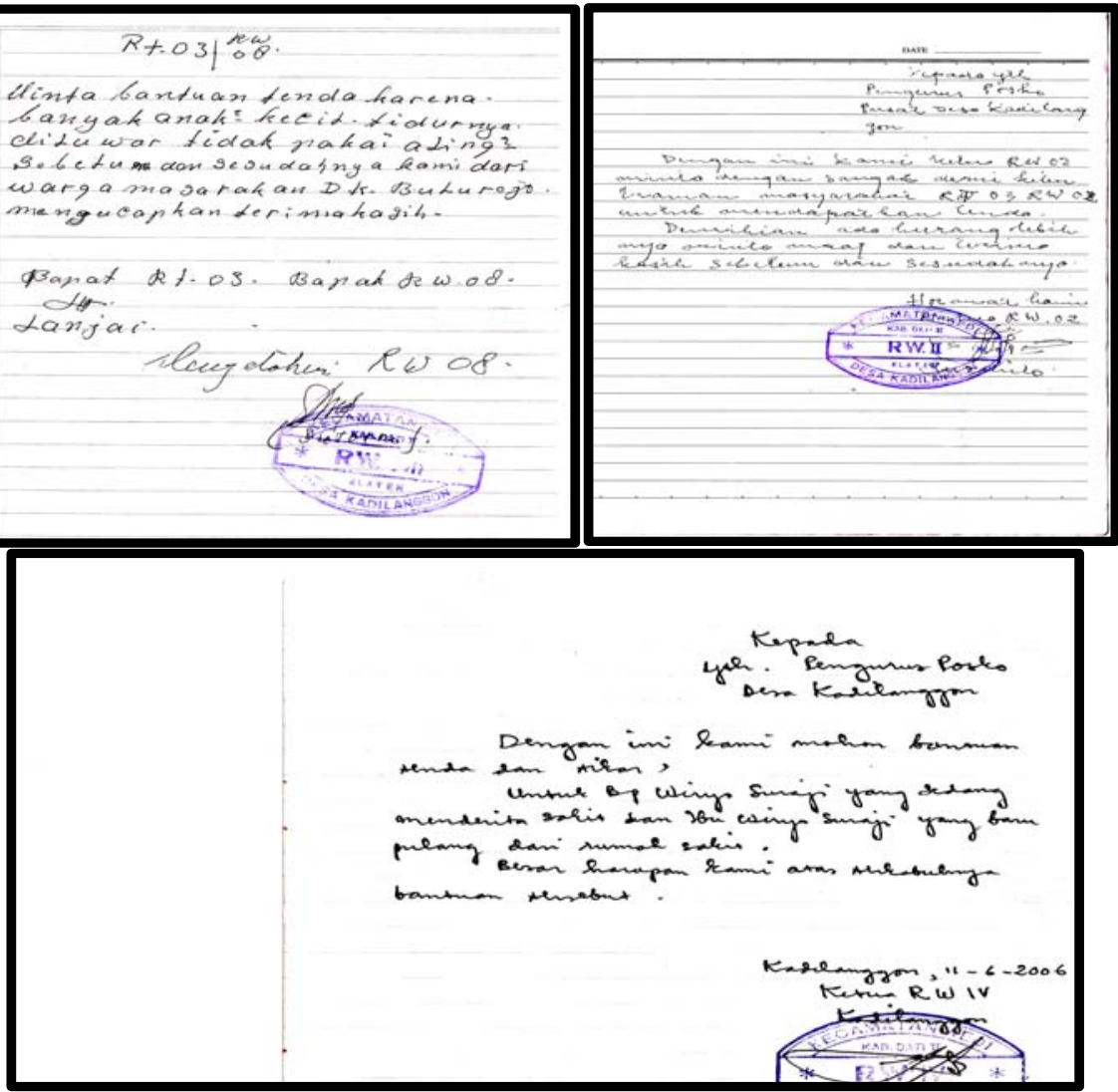
56 WARTA, Vol .10, No. 1, Maret 2007: 43 - 52 
58 WARTA, Vol .10, No. 1, Maret 2007: 43 - 52 
60 WARTA, Vol .10, No. 1, Maret 2007: 43 - 52 
